\title{
A Royal Traveler: American Press Coverage of King Kalākaua's 1881 Trip Around the World
}

\author{
DOUGLAS V. ASKMAN
}

\section{INTRODUCTION}

In JANUARY 1881, King Kalākaua embarked on a trip around the world. When he returned to his kingdom some nine months later, in October 1881, he had become the first reigning monarch to circumnavigate the globe. The king's trip took him to the United States twice. At the start of his journey Kalākaua traveled from Hawai'i to San Francisco in order to board a connecting ship for Asia. After spending a short time in California, the king proceeded to Japan. From Japan, Kalākaua made his way through East, Southeast, and South Asia and then arrived in Egypt. From there, the king sailed to Europe. After visiting a number of European countries, Kalākaua crossed the Atlantic, returning to the United States, this time to the East Coast. The last phase of the king's trip took him across America, arriving again at San Francisco. From California, Kalākaua returned to Hawai'i.

The king's journey garnered media attention around the world, including in many newspapers throughout the United States. However, Kalākaua's 1881 visit was not his first trip to the United States as king. In 1874, Kalākaua had travelled to America shortly after ascend-

Douglas V. Askman, Ph.D., is an associate professor of history at Hawai i Pacific University in Honolulu. He holds a Ph.D. and M.A. in history from the University of California, Los Angeles and a B.A. in history from the University of Hawai 'i at Mānoa.

The Hawaiian Journal of History, vol. $5^{1}$ (2017) 
ing the throne to negotiate a reciprocity treaty between his kingdom and the American government. This tour attracted much press coverage in the United States as it represented the first time in American history that a ruling monarch had visited.

The media attention that Kalākaua received during his American

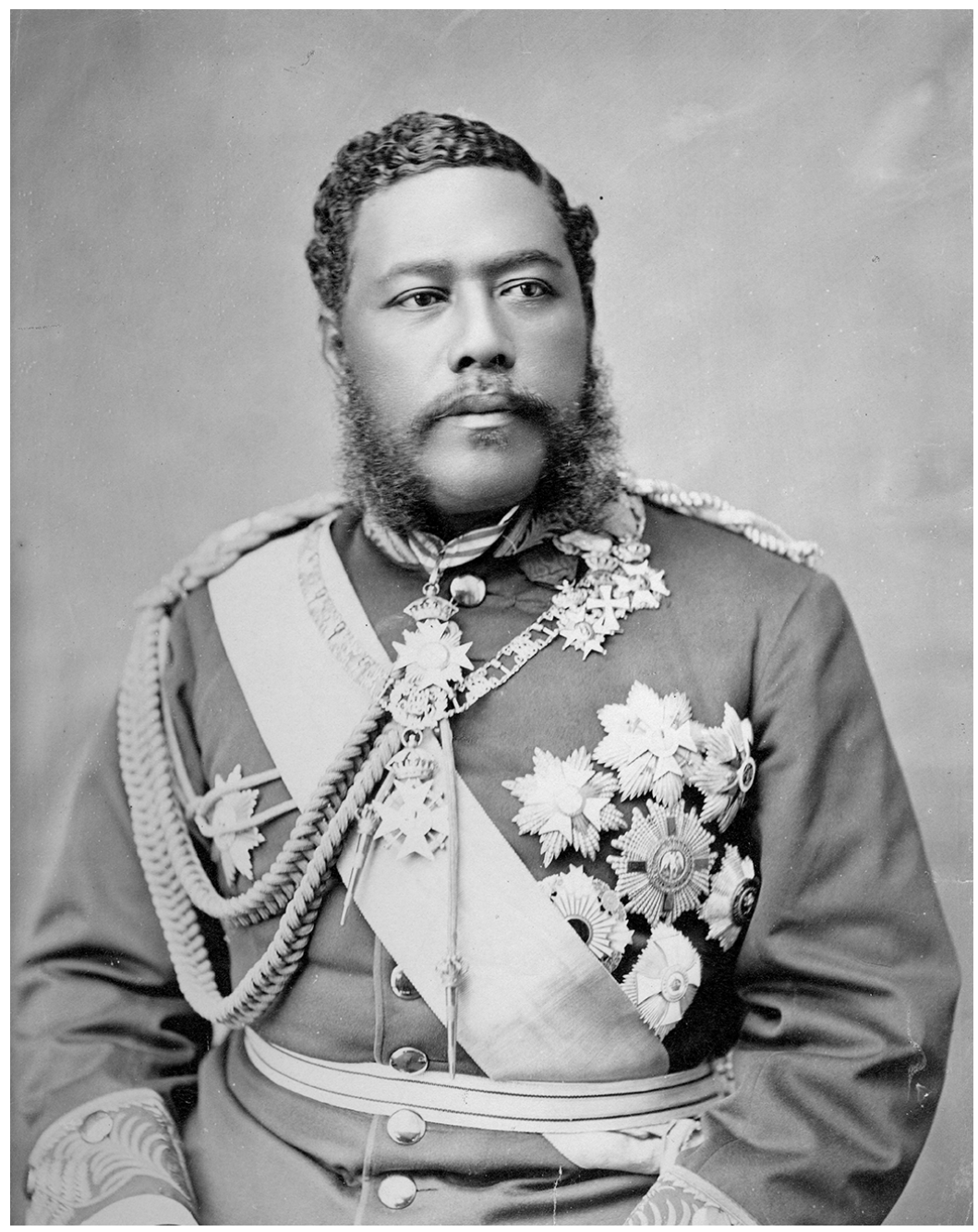

FiguRE 1. Kalākaua wearing several of the decorations awarded to him from countries he visited on his world tour, No Date. AH. 
visit at the start of his reign was repeated in 1881 during the king's world trip. Although American journalists gave special attention to Kalākaua's time in the United States, they covered the entirety of his journey. Two themes dominate American reporting of the king's trip. The first reflects the extent to which Kalākaua had achieved significant respect as an internationally recognized sovereign of an independent kingdom, demonstrating Hawai'i's status as a member of the family of nations. The second theme of American reporting of the king's trip, however, reflects the opposite, a lack of appreciation for Kalākaua as the head of state of a country that was equal to those in the West.

\section{Trip to California}

On January 20, 1881, Kalākaua left Honolulu bound for San Francisco, the first stop on his world tour. Even before the king's departure, the American press announced that Kalākaua was embarking on a long journey and would be visiting the United States. The Wichita City Eagle of Wichita, Kansas, reported on January 6 that the king would soon be leaving Hawai'i on a lengthy foreign trip and would mostly likely arrive in America in February. ${ }^{1}$ The True Northerner of Paw Paw, Michigan, added that the king had friends in Omaha, Nebraska, and intended to visit them. ${ }^{2}$ The Canton Advocate of Canton, South Dakota, in what was then the Dakota Territory, positively referred to Kalākaua as a friend of the United States. ${ }^{3}$

After a voyage of slightly more than a week, the king arrived in San Francisco. The Sacramento Daily Record-Union, published in California's capital, noted from press sources in San Francisco that "His Majesty Kalakaua, King of the Sandwich Islands" and his small entourage had reached the United States on January 29. The paper gave a brief summary of what it believed to be the Hawaiian monarch's itinerary. The Daily Record-Union explained that the king would stay in San Francisco briefly, then proceed to Asia, where he would examine the issue of immigration to Hawai' $i$. This would be followed by a journey to Europe and then to the East Coast of the United States, from where Kalākaua would make his way back to Hawai'i after crossing North America by train. ${ }^{4}$ Other American papers also noted that the king's trip included a search for immigrants to Hawai'i, with the New 
York Tribune of New York City printing a short item, "A KING SEEKING SUBJECTS." 5

American newspaper coverage of Kalākaua's visit to the United States at the beginning of 1881 was largely respectful, emphasizing the king's status as a friendly head of state. On February 1, the Wheeling Daily Intelligencer of Wheeling, West Virginia, included a short summary of Kalākaua's planned journey, which it titled "Our Royal

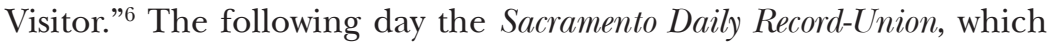
had frequent coverage of the king's visit to California, referred to Kalākaua as "His Majesty" in describing his visit to the Spring Valley Water Works in San Mateo, near San Francisco. ${ }^{7}$ On February 3, the Daily Record-Union covered Kalākaua's visit to California's capital city. The article, "DISTINGUISHED VISITOR," noted the king's Sacramento lodging and that Kalākaua was driven to the state capitol, where he met the governor of California. After the visit the governor had dinner with the king at his hotel. The Sacramento paper also stated that while at the state capitol Kalākaua was flanked by the leaders of the California legislature and introduced to members of the state Senate and Assembly. ${ }^{8}$ The Daily Record-Union also pointed out that the king visited the city of San Rafael in Marin County, and that a magnificent ball was given in his honor at the Palace Hotel in San Francisco. ${ }^{9}$ The New-York Tribune added that Kalākaua began the ball with a quadrille. ${ }^{10}$

On February 9, the Daily Astorian of Astoria, Oregon, published an editorial on the king's visit to the United States. The author had met Kalākaua in San Francisco, and the tone of his article was positive, referring to Kalākaua as "His Majesty" and noting that he had the pleasure of meeting the king at the Palace Hotel along with other Oregonians. The editorial went on to describe in detail the monarch's itinerary around the world, and the author wrote that Kalākaua was "the same pleasant and affable gentleman as when he last visited this city seven years ago, and received several proofs of the honor and esteem in which he is held." "11 A week later the Daily Astorian noted that the king, as a public figure, rightly wanted to avoid being treated like a celebrity and to escape being mobbed by crowds. ${ }^{12}$ Finally, following the king's departure from California, the Sacramento Daily Record-Union reported that San Francisco society benefitted from Kalākaua's presence as "greater luster was added by the presence of a real King."13 
Despite this positive coverage, not all of the reporting about the king's trip in the American press was flattering. On February 3, the Columbus Journal of Columbus, Nebraska, in discussing Kalākaua's desire to arrange for immigration to Hawai' $i$ on his journey offensively referred to his skin color. ${ }^{14}$ In early March the Weekly Miner of Butte, Montana, reprinted the comments of an unidentified East Coast journalist about the king's visit to California. The author suggested, at times using distasteful and racially charged language, that the king was incompetent, morally corrupt, and easily influenced by others, especially by the German-born American business magnate Claus Spreckels, who was at the time a friend of Kalākaua and a powerful figure in the Hawai'i sugar industry. ${ }^{15}$

The author indicated without supporting evidence that the true purpose of the king's world trip was a nefarious plot by Spreckels and other Americans to kill Kalākaua by, for example, subjecting him to "'a variety of climates, which his present constitution can not stand." Following the king's death, the writer continued, Americans would seize control of Hawai' $i$. Included among the plotters, the article surmised, was William Armstrong, a member of Kalākaua's cabinet, who was accompanying the king on his global voyage. Born in Hawai' $i$,

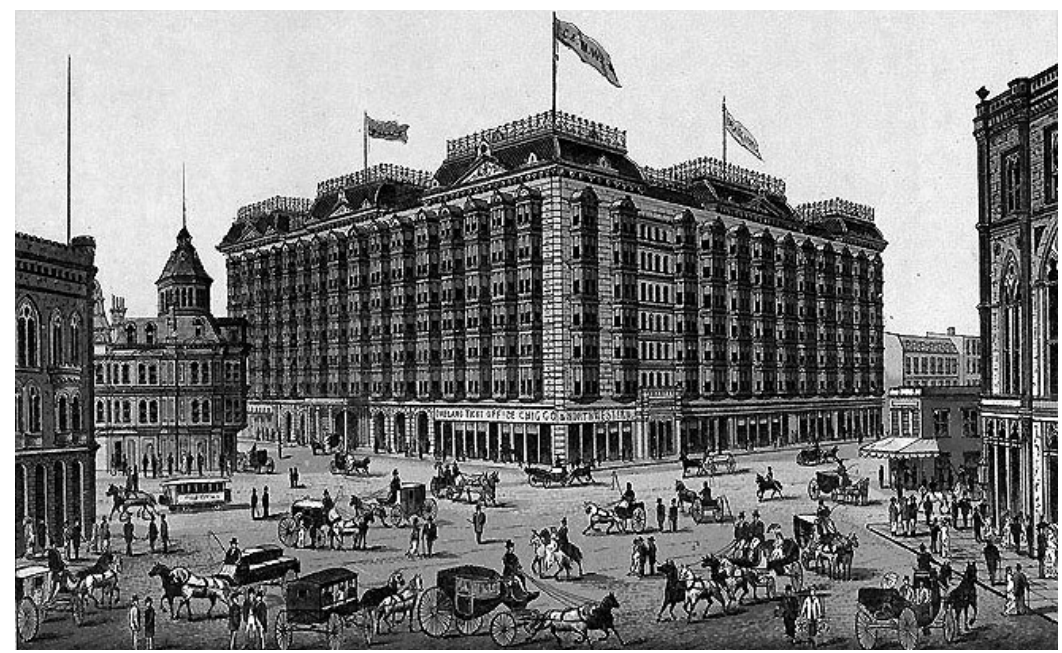

Figure 2. Palace Hotel, San Francisco, California. From Frank Leslie's Illustrated Newspaper, October 9, 1875 . 
Armstrong was the son of American missionaries and had been a lawyer in the United States before returning to the Hawaiian kingdom shortly before Kalākaua's trip. The unidentified journalist counted Armstrong, whom he referred to as a New Yorker, among the "schemers" planning the king's demise. ${ }^{16}$

\section{The King in Asia And Europe}

On February 8, 1881, Kalākaua left San Francisco bound for Japan, where he arrived on March 4. Although Kalākaua had departed the United States, the American press continued to report on the king's journey around the world. This media coverage continued the dual and often contradictory themes of portraying Kalākaua as an internationally recognized and respected monarch, while also negatively presenting him as a ruler who was not to be taken seriously, sometimes employing repugnant racial stereotypes.

While Kalākaua was at sea on his way to Japan, the Helena Weekly Herald of Helena, Montana, published on February 24 a brief, mocking commentary alleging that the king was planning to sell Hawai'i to the emperor of China. The Weekly Herald claimed that Kalākaua's intention was to sell his country in order to pay for another trip to the United States. ${ }^{17}$ The following day the New North-West of Deer Lodge, Montana, wrote that James A. Murray, a resident of Butte, Montana, had met the king in San Francisco. Murray reported that he was "not inclined to believe him [Kalākaua] the most intelligent sovereign the world has known." 18

In contrast, the same week that the Montana newspapers ridiculed the king, the Emporia News of Emporia, Kansas, praised the monarch's modesty and appearance. The paper reported that Kalākaua had the "good taste to dress simply, to wear no jewelry and no decorations. He is a remarkably handsome man, more than six feet in height. His carriage is erect, his beard, moustache, and eyes are black, and his expression is amiable." 19

Shortly after Kalākaua arrived in Japan, the Memphis Daily Appeal of Memphis, Tennessee, published a short piece on the king's travels and quoted the London paper the St. James Gazette. The reprint in the Daily Appeal reflects the dual nature of press coverage of Kalākaua's trip. The Gazette noted that the Hawaiian monarch's voyage would 
give satirists an opportunity to portray the king as an "uncivilized" ruler from a "savage" nation. However, the newspaper pointed out, Kalākaua was no such sovereign. Rather, the king "lives when he is at home in what is not miscalled a palace, where he has levees and dinner parties, with the menu printed on white silk and Sevres china on the table." ${ }^{20}$

Kalākaua departed Japan on March 22, 1881. The king then visited China and Hong Kong. Various American newspapers noted the great respect and honor that were accorded the monarch in East Asia. For example, the Vermont Phoenix of Brattleboro reported that

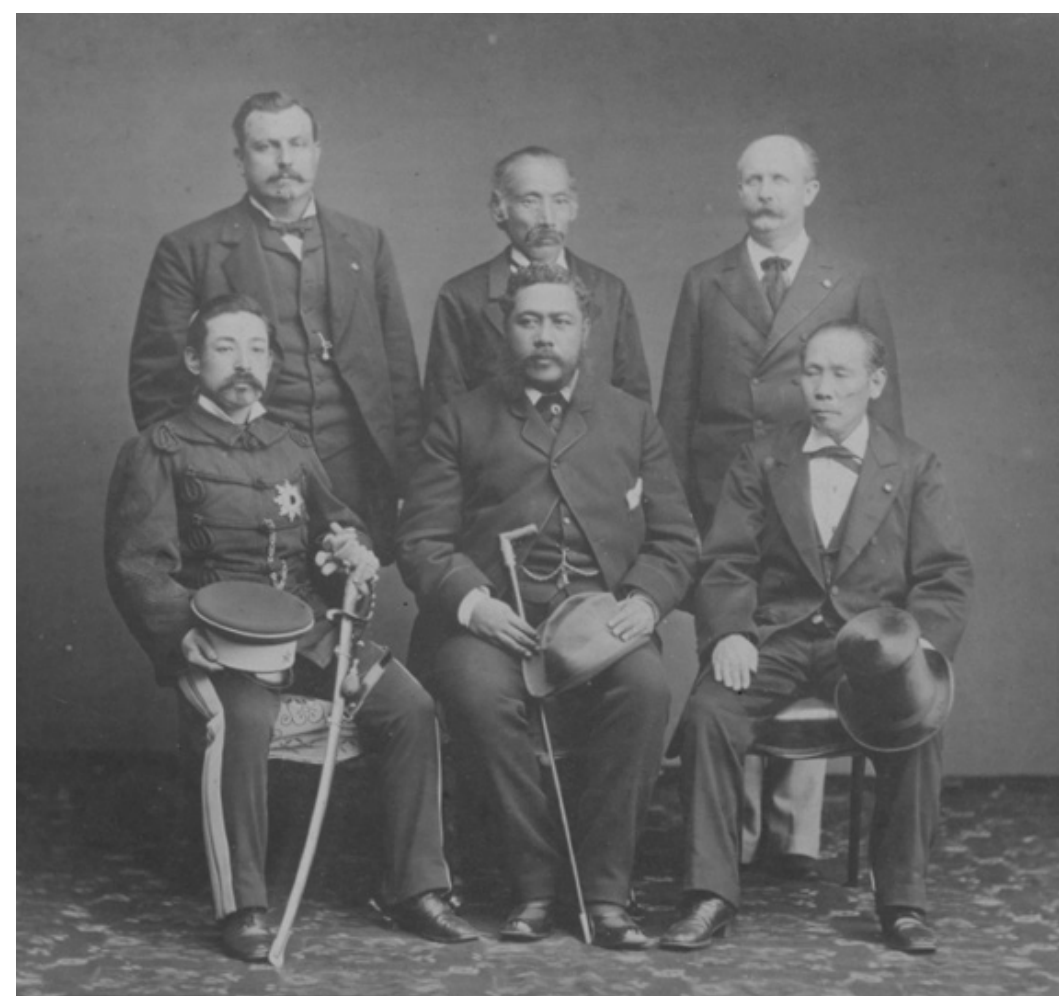

FIgURE 3. Kalākaua and his entourage in Japan with Japanese officials, 1881 . Top row, from left to right: Charles Judd; Jugai Tokuno Riyosaki, First Secretary of Finance; and William Armstrong. Seated, from left to right: Prince Yoshiaki, King Kalākaua, and Yoshie Sano Tsunetani, Minister of Finance. AH 
Kalākaua "has been received with great enthusiasm in Japan, the Emperor entertaining him elaborately." ${ }^{21}$ The Salt Lake Herald of Salt Lake City, Utah, announced that the king was "being feted in China and Japan." ${ }^{22}$ Similarly, the Arizona Weekly Citizen of Tucson explained that "King Kalakaua has been received with great respect by the Chinese and the foreigners in Shanghai." ${ }^{23}$ In a headline reading "A ROYAL BROTHER," the National Republican of Washington, D.C., citing the Hong Kong paper the China Mail, observed that Kalākaua was received with enormous honor by the Free Masons at the Victoria Lodge in Hong Kong. ${ }^{24}$

From East Asia Kalākaua journeyed to various destinations in Southeast and South Asia, eventually making his way to Egypt and Italy. Although there was some American press coverage of this segment of the king's trip, few details were provided. On July 7, Kalākaua arrived in London. Shortly after the king's appearance in the British capital, the Salt Lake Herald published an article, "Lionizing Kalakaua." The short piece noted that fashionable London society would be enlivened by the king's arrival and that Kalākaua was scheduled to have dinner with the British prime minister. However, in addition to providing a positive analysis, the article also stated that the king "drinks more than is good for him." ${ }^{25}$ The Daily Astorian of Astoria, Oregon, commented that the king "has certainly been very favorably received in official and aristocratic circles in London." ${ }^{26}$

\section{The "Sale" of the Hawaitan Kingdom}

By the time Kalākaua was in Europe, American press coverage of the king's trip was focused on the false notion that the purpose of the journey was to find a European buyer to whom he could sell the Hawaiian kingdom. The Lancaster Daily Intelligencer of Lancaster, Pennsylvania, described the supposed sale as an "auction" and stated that the kingdom's population was fast disappearing. ${ }^{27}$ The Salt Lake Herald, alluding to an editorial in the New York Times, printed an article, "A KINGDOM FOR SALE." It argued that American interests in Hawai ' $i$ would strongly object to the sale of the country to a European power. Indeed, the paper concluded that if Kalākaua attempted to transfer his kingdom to a European nation it might result in the United States seizing control of Hawai' $i$ in response. ${ }^{28}$ 
The widespread coverage of a supposed sale of the Hawaiian kingdom by Kalākaua reflects the lack of respect that was often shown to the king by the American press in its coverage of the monarch's world tour. It is highly doubtful that a foreign trip made by a Western head of state would have led to a common rumor in the American media that the leader was canvassing the globe looking for a buyer for his nation. Indeed, the publication of such speculation suggests that Kalākaua had so little regard for his own country that he would be willing to sell it for his personal financial gain. In addition, the circulation by the American press of rumors of Hawai'i's supposed impending "sale" did not take into account that Kalākaua, just like any leader of a Western nation, was a constitutional ruler who did not own Hawai' $i$ and did not have the legal authority to sell it.

American press speculation about Kalākaua's alleged plan to sell Hawai'i on his trip also fed into distasteful Western stereotypes of nonWestern peoples. In fact, the Sacramento Daily Record-Union announced in its coverage of the purported sale of the Hawaiian kingdom that the Hawaiian people would not object if Kalākaua were to sell his nation. The paper argued that "his people are so easy-going and indolent that they are not likely to raise any serious objections to the proposed transfer." ${ }^{29}$ The Daily Record-Union's reporting on the rumored sale of Hawai'i contrasts with the positive stories that the paper had published concerning Kalākaua's time in California, and reflects the dual nature of American press coverage of the king's trip.

Kalākaua's traveling party quickly put down the rumors that the king was going to sell Hawai'i. The New York Tribune reported on July 17 that William Armstrong had announced in London that speculation about the sale of Hawai' $i$ was entirely untrue. ${ }^{30}$ The Lancaster Daily Intelligencer added that Armstrong insisted that the king had no political motive in making his world tour, but that if he did, "it would rather be to obtain the guarantee of these [European] countries for the absolute independence of the islands." ${ }^{31}$

On July 29, 1881, the Salt Lake Herald noted in an article, "Pure Patriotism," that the Hawaiian diplomatic representative to the United States, Elisha H. Allen, had informed the New York Times that Kalākaua had absolutely no intention of selling the Hawaiian kingdom. Allen asserted that the king supported the independence of Hawai' $i$ and that his travels included efforts to find immigrants to boost the 
nation's declining population. Reiterating Allen's statements, the Herald reported that Kalākaua's journey was for "patriotic purposes and will undoubtedly be of great value to his own people." ${ }^{22}$ The paper concluded that "the idea of the sale of the kingdom is as abhorrent looking to the King as the same act would be to any sovereign in Europe." ${ }^{33}$ In other words, Kalākaua was no less a supporter of his country's independence than any leader in the Western world would be. The same day, the Lancaster Daily Intelligencer, reporting on Allen's comments, wrote that Hawai'i was a "constitutional monarchy, and that the king can hardly sell out the Islands as if they were his private property." 34

The theme of the king's status as a monarch equivalent to any Western ruler was echoed in an interview that Kalākaua himself and his advisor William Armstrong gave in Paris to a reporter from the New York Herald. The contents of this interview were published in various newspapers across the United States. When asked about the rumored sale of the Hawaiian kingdom, Kalākaua replied, "'I first saw the story at Cairo, but it was too ridiculous, I thought, to need contradiction. In London, however, I saw the story repeated there. There is not a word of truth in it." 35 The king went on to explain that Hawai' $i$ was a constitutional monarchy with a parliament, making any attempt by himself to simply sell off the kingdom impossible. Armstrong also noted to the reporter that "'Queen Victoria might just as reasonably be suspected of bartering away British independence." "36 The king agreed. Kalākaua concluded by explaining that the real purposes of his world trip were tourism, health, and exploring the possibility of bringing immigrants to Hawai' $i$. The correspondent from the Herald ended his article by arguing that "far from King Kalakaua wishing to cede his kingdom to anyone, one of the chief objects of his voyage is to find some power which would be willing to guarantee its complete independence." 37

\section{The King on the East Coast of the United States}

On September 12, the New York Tribune published an interview with William Armstrong, who was traveling with the king on his world journey and had arrived in New York shortly before Kalākaua. Armstrong was the attorney-general of the Kingdom of Hawai' $i$ and was also 
tasked with investigating various possibilities for bringing immigrants to the islands. In his interview Armstrong summarized Kalākaua's travels. Armstrong noted the splendid treatment that the king had received while abroad, especially in Japan. The attorney-general also explained that the monarch had received a positive reception in China, Hong Kong, Thailand, and Egypt. In Europe, Armstrong remarked that Kalākaua had met with the kings of Italy, Belgium, and Portugal, in addition to Queen Victoria of Great Britain and the pope. The interview with Armstrong ended with the king's advisor announcing that Kalākaua would soon be sailing from Liverpool to New York. The attorney general also named many of the decorations that the Hawaiian king had received from monarchs around the world. ${ }^{38}$

The Public Ledger of Memphis, Tennessee, published a summary of the king's second visit to the United States during his world tour. Kalākaua would make several stops on the East Coast, including New York City and Washington, D.C. The monarch would then travel by train to Kentucky to examine horses and possibly buy several to ship to Hawai'i. From there, Kalākaua would make his way overland to San Francisco, departing California for Honolulu on October 22. ${ }^{39}$

On September 23, Kalākaua reached New York City from Liverpool. He learned upon his arrival that the American president, James Garfield, who had been shot by an assassin on July 2, had died on September 19. Indeed, on the same day as the king's arrival, President Garfield's funeral took place in Washington. The Evening Critic, published in the American capital, reported that as a head of state, Kalākaua, "among his first acts upon landing was to send a message of sympathy and condolence to Mrs. Garfield." 40

American press coverage of the king's second 1881 visit to the United States then continued its twin themes, acknowledging Kalākaua as a recognized sovereign of an independent nation while also at times denigrating the monarch and his country. Indeed, these dual themes were sometimes apparent in a single account of the king's time in America. The day after Kalākaua arrived in New York, the Salt Lake Herald published an article on his trip to the United States. The paper identified the king as the royal leader of a self-governing country, declaring, "Again the soil of the United States is being trodden by a King, a real monarch, who tags to his signature the royal 'R."'41 The Hawaiian king was the equal of any European sovereign, and the 
Herald wrote, "Kalakaua is a royal as Alexander [Alexander III, the Emperor of Russia], as Wilhelm [Wilhelm II, the German Emperor], as Francis Joseph [Francis Joseph I, the Emperor of Austria], or as good old Victoria [Queen of Great Britain]." ${ }^{42}$ The journal also noted that Kalākaua had visited Utah during his 1874 trip to the United States. However, his time in the state had been short, and the king announced that on his next visit to the United States he would have an in-depth tour of Salt Lake City. With Kalākaua back in America, the Herald hoped that he would stop in Utah on his trip from the East Coast back to San Francisco. The paper wrote, "We want the King to come, for it is not likely that any other monarch will stray so far as this from his dominions." ${ }^{3}$ The Pulaski Citizen of Pulaski, Tennessee, added that "a real live king is in this country." ${ }^{44}$ But the journal remarked that the king's visit was being overshadowed by the death of President Garfield.

Despite the recognition by the Herald that Kalākaua was the leader of a sovereign country, and the fact that the paper wanted the king to stop in Salt Lake City, the journal was quick to point out that it did not believe that Hawai'i was a very important nation. The Herald, in fact, claimed, "It is true his kingdom is not much of a country, and his subjects are inclined to be insignificant as to numbers." ${ }^{45}$ In another item about Kalākaua's visit to the United States, published in the Herald the same day, September 24, the paper quoted from an interview with William Armstrong in the New York Evening Post. Armstrong, although an official of the Hawaiian government, held to the prevalent racist and paternalist view of Westerners of the time that Western civilization was superior to all others. As a result, the attorney general told the Post that Kalākaua was planning to visit the Hampton Institute in Virginia while on the East Coast. Established after the American Civil War, the Hampton Institute was a school that educated African Americans and later Native Americans as well. Armstrong claimed that at the Hampton Institute, which was run by Armstrong's brother, Samuel C. Armstrong, a Union officer during Civil War, the "system of educating natives to systematic civilized work will be studied by Kalakaua." "46 This disparaging view of non-Western peoples was echoed by the Herald. Also on September 24, the Sacramento Daily Record-Union mockingly noted that Hawai'i had a very small military and linked that to the rumors that Kalākaua was planning to sell his country during 
his world tour. ${ }^{47}$ The king was even personally criticized by the Daily Globe of St. Paul, Minnesota. The paper summarized Kalākaua's time on the East Coast by claiming that while "having a jolly time in the Eastern cities," he appeared "to have a high appreciation for American whiskey and la-women."48

Partly due to the death of President Garfield, the king's activities in New York were limited and of a personal nature. The Sun, published in New York, which referred to the king respectfully as "His Majesty," reported Kalākaua's activities in detail in an article, "RECREATIONS OF ROYALTY." For example, the monarch went to see the widow of William Little Lee, the American-born chief justice of the Hawai' $i$ Supreme Court who had died in 1857 . In addition, Kalākaua visited Coney Island for pleasure, where he attracted the attention of the public despite trying to conceal his true identity. ${ }^{49}$

After his brief stay in New York, the king headed to Washington via Philadelphia. At a brief stop in Philadelphia, the Philadelphia Times interviewed Colonel Charles H. Judd, the king's chamberlain and one of his two primary traveling companions along with William Armstrong. Judd summarized Kalākaua's time in New York and highlighted the king's visit with Thomas Edison. Judd added that Kalākaua desired to see the widespread introduction of electricity to Honolulu. The chamberlain also noted that shortly before leaving New York the former American president Ulysses Grant had called on the king. Grant had been president when Kalākaua had visited the United States in 1874, and Judd noted that the two statesmen "had quite a familiar conversation." ${ }^{50}$

The king arrived in Washington on September 27. The National Republican, published in the American capital, noted the positive reception that the Hawaiian monarch had received on his last visit to Washington. "He was here in 1874 , and remembers most pleasantly the reception tendered to him by the citizens of the District [of Columbia]." ${ }^{1}$ The paper also described the king as having a "very pleasant and agreeable manner." ${ }^{2}$ As the recognized sovereign of a friendly nation, the purpose of Kalākaua's visit to Washington was "mainly to call upon the President."53 The National Republican concluded in its article about the king's trip that Hawai'i had been significantly influenced by the West, stating that Kalākaua and his advisors were wearing Western clothes, "the style of dress which prevails in 
their country." ${ }^{54}$ It was also pointed out that the king spoke English with only "a slight foreign accent." ${ }^{54}$ Slightly more than a week later, the National Republican wrote that a United States senator was said to have remarked that Kalākaua was "one of the best-informed and educated men he has met."56

The Evening Star of Washington echoed some of the positive sentiments of the National Republican, describing the monarch as goodnatured and indicating that Washingtonians were familiar with him due to his previous visit in 1874 . The Star even provided a description of Kalākaua's height and weight, noted his age, and gave a description of what the sovereign was seen wearing. The paper stated that the king had attracted much media attention in the American capital and that his presence had generated a "rush of reporters, ambitious to interview a real live monarch." ${ }^{57}$ The Star also described the departure of Kalākaua and his staff from his hotel on September 28 to call on President Chester A. Arthur, who had succeeded the assassinated President Garfield.

The Memphis Daily Appeal described the king's visit to the president, who was not in residence at the White House at the time, but rather at a private home. Kalākaua's appointment with the president certainly confirmed his status as a recognized sovereign, and the king was accompanied from his hotel by Assistant Secretary of State Robert R. Hitt, who introduced Kalākaua's entourage to President Arthur. The two heads of state met for about twenty minutes. ${ }^{58}$

On the same day as his visit with President Arthur, the king departed Washington in order to visit the Hampton Institute and nearby Fort Monroe in Hampton, Virginia. Fort Monroe, an American military facility, was noted for remaining in Union hands during the Civil War despite Virginia's status as a member of the Confederacy. In order to facilitate Kalākaua's visit to Fort Monroe the American government provided an official ship, the Dispatch. The vessel was sent from New York to Virginia by the secretary of the navy to "be placed at the disposal of King Kalakaua." 59 The Salt Lake Herald also wrote that "extensive preparations" were made at Fort Monroe in preparation for the king's visit. ${ }^{60}$

Kalākaua received a grand and dignified reception in Virginia on September 29. The Memphis Daily Appeal reported that as he arrived "a battalion with a band paraded on the wharf to receive him." ${ }^{1}$ The 
commander of Fort Monroe greeted the king, and Kalākaua eventually made his way to Hampton Institute. After spending much of the day there the king visited the government-operated old soldiers' home in Hampton "where a salute was fired in his honor." ${ }^{62}$ At the end of the day Kalākaua hosted a reception. Before returning to Washington the king also visited the naval yard at Norfolk, Virginia where he was received by the commandant. The Lancaster Daily Intelligencer also noted that "the yards of the receiving ship were manned and a royal salute of 21 guns was fired." 63

\section{The Journey Back Home}

After his time on the East Coast of the United States, Kalākaua made his way across the country via train heading to San Francisco, where the king planned to depart California for Hawai'i on October 22. On this cross-country journey, Kalākaua made a number of stops. American press coverage of this last leg of the king's world trip continued the twin themes of positive reporting on a respected and recognized head of state traveling in the United States, and less favorable coverage belittling Hawai'i and its monarch.

Leaving Washington, Kalākaua proceeded to Lexington, Kentucky, where he was expected to buy horses. On the morning of October 3, the king and his entourage arrived in Cincinnati, Ohio, where they stopped briefly before taking the first train to Lexington. ${ }^{64}$ Referred to courteously as "His Majesty," the Cincinnati Commercial listed the members of the king's party giving their formal titles. In Cincinnati, Kalākaua ate breakfast at a hotel before continuing to Lexington. ${ }^{65}$ In Lexington, Kalākaua was greeted at the train station by William Temple Withers, a former Confederate general and well-known horse breeder. The Commericial reported that the king "visits Lexington for the purpose of inspecting in person some of the fine thoroughbred horses for which this section is so famous, and will very probably purchase several of them to take to his island home."66 The paper also noted that Kalākaua had previously purchased horses from Withers and was so pleased with them that he wanted to make a personal visit to Kentucky to inspect additional specimens. In light of this the Commercial wrote, "we are indebted for the favor of his royal presence at present." ${ }^{67}$ However, since the king was traveling privately, the jour- 
nal added that there would be no official events to honor Kalākaua's brief stay in the city. The Commercial also remarked that the king was a "quiet, gentlemanly-appearing man" and "extremely refined." ${ }^{68}$ The paper concluded by stating that Lexington "would take pleasure in extending an ovation worthy of his royal position, but he seems to avoid display of every kind, and his wish, of course, will be respected." ${ }^{69}$

After overnighting in Lexington, the king continued his journey. On October 5, Kalākaua reached Chicago, where he changed trains and departed for Omaha the same day. ${ }^{70}$ The Chicago Tribune reported on the king's very brief time in Chicago. The paper wrote that Kalākaua had eaten breakfast in the city and left for Omaha at noon. The Tribune was able to secure a short interview with Kalākaua during his Chicago stopover. During the meeting the king discussed his world tour, and the paper noted that "he was everywhere received with the greatest kindness." ${ }^{.11}$ Kalākaua also reflected on the differences in the United States that he observed since his last visit in 1874 and said that electricity would soon be introduced to his kingdom.

The Omaha Daily Bee reported on the king's time in Nebraska with an article, "TRAVELING ROYALTY." 72 The paper pointed out that it was Kalākaua's second visit to Omaha as he had stopped in the city on his previous trip to the United States. The Daily Bee's coverage of the monarch's visit was especially positive, and the journal declared, "Once again Omaha throws open her hospitable doors to the son of destiny from the Sandwich Islands." ${ }^{\text {73 }}$ The Daily Bee went on to point out that Omaha was one of the few stops on the king's trek across the United States and announced that those "who have never had the good fortune to gaze upon one through whose veins pulsate the blood royal may now have an opportunity of seeing a real live king." 74

The paper remarked that the time of Kalākaua's exact arrival in the city had been unknown but that several people had waited for over an hour at the train station to catch a glimpse of the monarch. When the train arrived, the king was greeted by James Mills Woolworth, a judge and the first city attorney of Omaha, accompanied by an official of the railway company. The royal party travelled by carriage to Woolworth's mansion. The Daily Bee provided a brief biography of the king and described in some detail Kalākaua's trip around the world, noting that in San Francisco "he was entertained most sumptuously, as he 
has been at the courts of the various countries on his programme." 75 The paper went on to describe that the king had been a guest of the emperor of Japan, visited China, been entertained in Hong Kong by the British governor, and stopped in Thailand. From there, the Daily Bee continued that Kalākaua had been hosted by the ruler of Egypt, the king of Italy, the pope, and Queen Victoria. The journal concluded its description of the king's travels by pointing out his visits with the king of Belgium, a prince of the German imperial family, and the king of Portugal. ${ }^{76}$

At the Woolworth mansion Kalākaua was treated to a dinner and reception with an orchestra in attendance and dancing well into the night. The Daily Bee reported that the king enjoyed himself and gave a description of Kalākaua, summarizing that "his whole appearance bespeaks frankness and good nature."77

From Omaha the king traveled directly to California and arrived in San Francisco on October 1 1. During his stay in the city Kalākaua did some sightseeing, including a drive through Golden Gate Park, visited

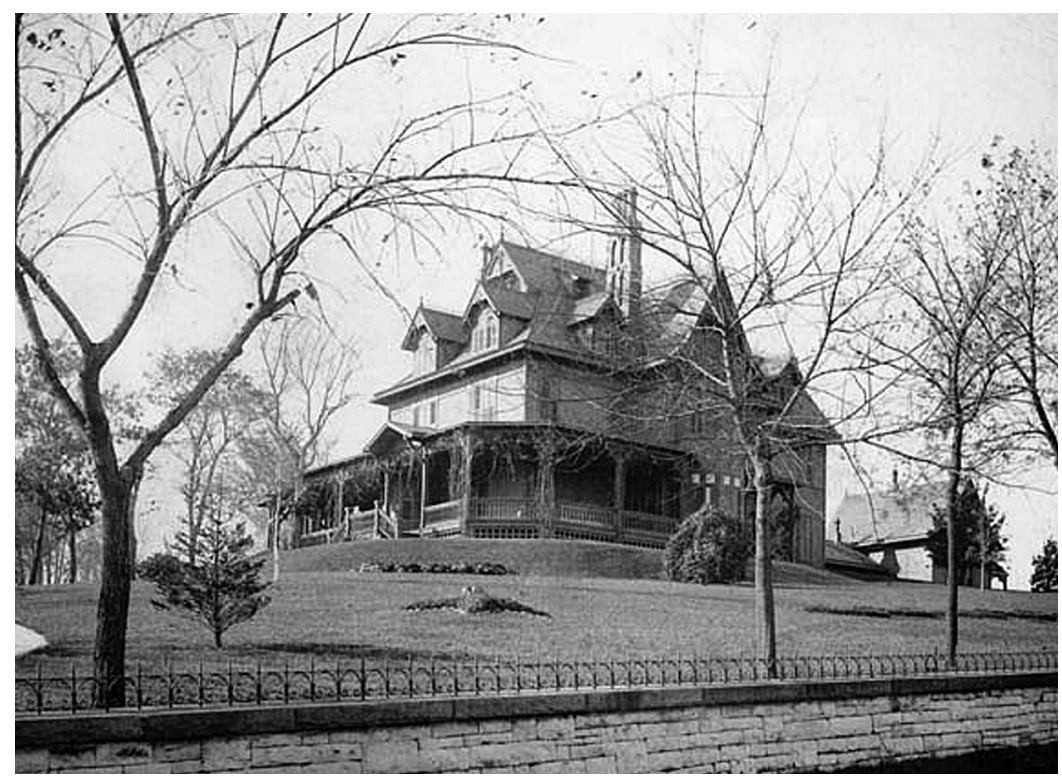

Figure 4. Residence of James Woolworth in Omaha, Nebraska. From Morton, J. Sterling. Illustrated History of Nebraska. Lincoln: Jacob North \& Company, 1906. 
various businesses, and attended the theater ${ }^{78}$ The Daily Los Angeles Herald reported that on the last night of his stay in San Francisco the monarch attended a banquet organized in his honor at the Palace Hotel. Before the banquet, a reception was also held in the hotel. Among the guests were George Clement Perkins, the governor of California, Irvin McDowell, a Union general from the Civil War, and "about fifty prominent citizens." ${ }^{79}$ On October 22, Kalākaua departed the United States for Honolulu. A week later, on October 29, the king landed on $\mathrm{O}^{\prime}$ ahu completing his world tour.

Not all of the press coverage of the king's travels during his journey across the United States was sympathetic. For example, while the reporting of the Omaha Daily Bee on Kalākaua's stay in Nebraska was extremely positive, the Omaha Republican's coverage was the exact opposite. The Republican's analysis of the king's visit to Omaha was mocking and sarcastic. The paper wrote that it interviewed a man who was at the train station in the city when the monarch arrived. The unidentified man, who maintained that he had visited Hawai' $i$, said, "'It's very amusing to see how much some people think of him." "80 The individual continued by making fun of the small size of the Hawaiian kingdom, claiming that it "embraces about as many people as the combined population of Omaha and Council Bluffs." "11 As a result, the man concluded, "there is about as much propriety in calling him a king as there would be in applying the title to the mayor of Omaha."”82

The Republican wrote that the unnamed man asserted that he learned about Kalākaua during a brief stop in Honolulu during a trip to Australia. Without citing evidence, the man declared that the king was a puppet of con-men, who had engineered his election as king. Using racially charged language against Kalākaua and his people, the individual accused the king of being at his accession "'little better than a man of leisure or common loafer on the streets." "83 Additionally, the world tour was described as a scheme by those manipulating the monarch to get him out of the kingdom.

Other papers reiterated some of the negative themes of the Omaha Republican. Two days after Kalākaua arrived in San Francisco, the Jackson Standard of Jackson, Ohio, noted that the king claimed to be the first monarch to have circumnavigated the globe. Mocking the small size of the kingdom, the paper said that the king could have taken the population of the country with him in a train car. ${ }^{84}$ 
While Kalākaua was in California, the Northern Pacific Farmer of Wadena, Minnesota, published a brief story on the king, which appeared in other newspapers as well, and was based on a sarcastic letter written to a paper in Philadelphia. The author claimed, using unsubstantiated references to Kalākaua's 1874 visit to New York, that the king drank excessively. The article also made an offensive comment about the monarch's skin color and asserted mockingly that the purpose of the king's trip was to "stock his islands with foreigners." 85

\section{Conclusion}

On October 29, 1881, Kalākaua returned to Honolulu after a world tour of approximately nine months. On his return, he became the first ruling monarch to circumnavigate the globe. Kalakkaua visited the United States twice during his travels. Departing Hawai'i, he landed first in California on his way to Japan at the beginning of his trip. After making stops in Asia, Africa, and Europe, the king arrived in New York on his way back home. After visiting several destinations on the East Coast, Kalākaua travelled by train to San Francisco from where he departed the United States.

The American press extensively followed the king's voyage, emphasizing especially Kalākaua's time in the United States. American coverage of the trip focused on two often contradictory themes. On the one hand, papers frequently highlighted Kalākaua's status as an internationally recognized sovereign whose presence in the United States deserved positive attention and respect. On the other hand, the American press often underlined the opposite view as well, that the king and his country were insignificant and not to be acknowledged to the extent of Western nations. The first view reflected the successful efforts that Kalākaua and the Hawaiian monarchy had made in creating a positive international reputation for the kingdom. This was seen, for example, by the impressions that were generated by the king's 1874 trip to United States, which were sometimes alluded to during media coverage of the 1881 world tour. Nevertheless, negative reporting on the king's journey revealed the geographical, cultural, and ethnic disdain that the Hawaiian Kingdom faced as a small, Polynesian nation in the middle of the Pacific. 


\section{Notes}

1 Wichita City Eagle (Wichita, Kansas), January 6, 1881.

2 True Northerner (Paw Paw, Michigan), January 7, 1881.

Canton Advocate (Canton, Dakota Territory), January 13, 1881.

${ }^{4}$ Sacramento Daily Record-Union (Sacramento, California), January 31, 1881.

5 New-York Tribune, February 1, 1881.

6 Wheeling Daily Intelligencer (Wheeling, West Virginia), February 1, 1881.

7 Record-Union, February 2, 1881.

8 Record-Union, February 3, 4, 1881.

${ }^{9}$ Record-Union, February 5, 8, 1881, pg. 4. The king would later die at the Palace Hotel in January 1891.

${ }_{10}$ New-York Tribune, February $17,1881$.

${ }_{11}$ Daily Astorian (Astoria, Oregon), February 9, 1881.

12 Astorian, February 16, 1881.

${ }_{13}$ Record-Union, February 21, 1881.

${ }^{14}$ Columbus Journal (Columbus, Nebraska), February 3, 1881.

15 Weekly Miner (Butte, Montana), March 8, 1881.

${ }_{16}$ Miner, March 8, 1881; In 1904, William Armstrong published a lengthy, but biased account of the king's world trip. It incorporated many of the cultural and ethnic stereotypes often held by Westerners of the time. William N. Armstrong, Around the World with a King (Honolulu: Mutual Publishing, 1995.)

17 Helena Weekly Herald (Helena, Montana), February 24, 1881.

8 New North-West (Deer Lodge, Montana), February 25, 1881.

${ }_{19}$ Emporia News (Emporia, Kansas), February 25, 1881.

20 Memphis Daily Appeal (Memphis, Tennessee), March 10, 1881.

1 Vermont Phoenix (Brattleboro, Vermont), May 6, 1881.

2 Salt Lake Herald (Salt Lake City, Utah), May 1o, 1881.

${ }^{3}$ Arizona Weekly Citizen (Tucson, Arizona), May 15, 1881.

4 National Republican (Washington, D.C.), July 29, 1881.

5 Herald, July 12, 1881.

6 Astorian, July 26, 1881.

7 Lancaster Daily Intelligencer (Lancaster, Pennsylvania), July 13, 1881.

Herald, July 15, 1881.

Record-Union, July 15,1881 .

Tribune, July 17,1881 .

1 Daily Intelligencer, July 18, 1881.

2 Herald, July 29, 1881.

3 Herald, July 29, 1881.

Daily Intelligencer, July 29, 1881.

${ }^{5}$ Herald, August 13, 1881.

${ }^{36}$ Public Ledger (Memphis, Tennessee), August 16, 1881.

7 Ledger, August 16, 1881.

8 Tribune, September 12, 1881.

9 Ledger, September 15, 1881. 
${ }^{40}$ Evening Critic (Washington, D.C.), September 23, 1881.

${ }^{41}$ Herald, September 23, 1881. Many monarchs sign their names with their first name followed by the letter "R." "R" stands for the Latin word "rex," meaning "king." Queens similarly sign their names followed by the letter " $R$ " where "R" signifies "regina," Latin for "queen."

${ }^{42}$ Herald, September 23, 1881.

${ }^{43}$ Herald, September 23, 1881.

${ }^{44}$ Pulaski Citizen (Pulaski, Tennessee), September 29, 1881.

45 Herald, September 23, 1881.

46 Herald, September 23, 1881.

${ }^{47}$ Record-Union, September 24, 1881.

48 Daily Globe (St. Paul, Minnesota), October 2, 1881.

49 Sun (New York), September 25, 1881.

${ }^{50}$ Excerpts from the Philadelphia Times reprinted in the Dallas Daily Herald (Dallas, Texas), October 4, 1881.

${ }_{51}$ Republican, September 28, 1881 .

${ }^{52}$ Republican, September 28, 1881 .

${ }_{53}$ Republican, September 28, 1881.

${ }^{54}$ Republican, September 28, 1881.

${ }_{55}$ Republican, September 28, 1881.

56 Republican, October 8, 1881.

57 Evening Star (Washington, D.C.), September 28, 1881.

58 Daily Appeal, September 29, 1881.

59 Republican, September 29, 1881; Stark County Democrat (Canton, Ohio), September 29, 1881 .

${ }^{60}$ Herald, September 29, 1881.

${ }^{61}$ Daily Appeal, September 30, 1881.

${ }^{62}$ Daily Appeal, September 3o, 1881.

${ }^{63}$ Daily Intelligencer, October 1, 1881.

${ }^{64}$ Star, October 3, 1881.

${ }^{65}$ Excerpts from the Cincinnati Commercial (Cincinnati, Ohio) reprinted in the Ledger, October 6, 1881.

${ }^{66}$ Excerpts from the Cincinnati Commercial (Cincinnati, Ohio) reprinted in the Ledger, October 6, 1881.

${ }^{67}$ Excerpts from the Cincinnati Commercial (Cincinnati, Ohio) reprinted in the Ledger, October 6, 1881.

${ }^{68}$ Excerpts from the Cincinnati Commercial (Cincinnati, Ohio) reprinted in the Ledger, October 6, 1881.

${ }^{69}$ Excerpts from the Cincinnati Commercial (Cincinnati, Ohio) reprinted in the Ledger, October 6, 1881.

${ }^{70}$ Daily Appeal, October 6, 1881.

71 The Chicago Tribune article was reprinted in the Advocate, October 20, 1881.

72 Omaha Daily Bee (Omaha, Nebraska), October 7, 1881.

${ }^{73}$ Daily Bee, October 7, 1881. 
${ }^{74}$ Daily Bee, October 7, 1881.

75 Daily Bee, October 7, 1881.

76 Daily Bee, October 7, 1881.

77 Daily Bee, October 7, 1881.

78 Record-Union, October 11, 1881; Daily Bee, October 12, 1881.

${ }^{79}$ Daily Los Angeles Herald, October 23, 1881.

${ }^{80}$ The article in the Omaha Republican (Omaha, Nebraska) was reprinted in the Fairfield News and Herald (Winnsboro, South Carolina) on December 21, 1881.

${ }^{81}$ News and Herald, December 21, 1881.

82 News and Herald, December $21,1881$.

83 News and Herald, December $21,1881$.

${ }^{84}$ Jackson Standard (Jackson, Ohio), October 13, 1881.

85 Northern Pacific Farmer (Wadena, Minnesota), October 20, 1881. Other papers, such as the Worthington Advance (Worthington, Minnesota) and the Jamestown Alert (Jamestown, Dakota Territory) also published the same story. 